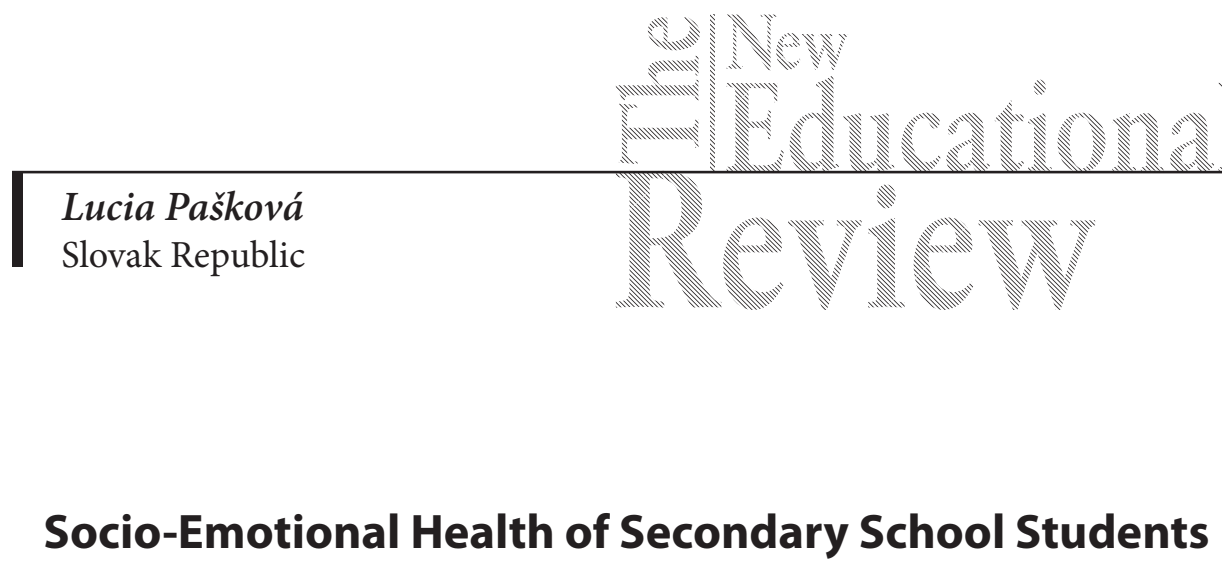

DOI: 10.15804/tner.2017.48.2.09

\begin{abstract}
The article deals with the subject of students' mental health, which has been so relevant in recent years. It is based on Furlong's concept and theory of socio-emotional health. We tried to discover relations between dimensions and their indicators of socio-emotional health and subjective happiness with orientation to Slovak secondary school students. We used the Social-Emotional Health Survey questionnaire, version for adolescents (SEHS-S), and our results solidly confirmed a positive relationship between experiencing happiness and dimensions of socio-emotional health.
\end{abstract}

Keywords: mental health, happiness, students, socio-emotional health

\title{
Introduction
}

Health mostly occupies uppermost positions in the value hierarchy of every one of us and is one of every person's basic rights. "Good health" contributes to the quality of life, life satisfaction and subjective well-being.

Mental health in a broader sense is understood as an optimal mental condition characterized by adequate perception of reality, adequate autonomy, positive self-concept, self-confidence, good social adjustment, personal integrity with the focus on a meaningful life goal.

Becker (1995) characterizes mental health as a relatively changeable condition reflecting, on the one hand, the current mental state, while, at the same time, it may acquire also the character of a stable personality characteristic. It is conceived as derived from coping with external and internal requirements; and psychological 
competences, essential for coping with such requirements, as well as positive emotions, are considered preconditions of mental health. According to Becker, the structure of mental health consists of components integrating psychological and physical subjective well-being, self-realization and positive self-evaluation. Internal (personality) and external (upbringing) sources of positive self-concept in Slovak adolescents have been dealt with by Duricová, Lukáčová (2016a) and Ďuricová, Hašková (2016b).

Health is no longer perceived as the opposite of disease or absence of subjective difficulties, but it is considered a state of wholeness and integration (Rycroft, 1993); highlighted are such constructs as mental or social health. The issue of social health has been dealt with, e.g., by Kozoň (2013). He considers social health of individuals and society to be a relatively comprehensive health state, with bio-psycho-social and spiritual content, of the whole organism consisting of the personality of an individual, individuals, social groups, communities living in harmony with the natural and social environment. Individuals find the source of their health in their direct surroundings, in social relations - family, friends, community, region, country, in the harmony of internal environment of the human organism as a unique individual and society in the narrow (family) and broad sense. It is a relationship between the internal environment (bio-psycho-social and spiritual space) and attributes of personal freedom, feelings and evaluation of attitudes to the outer environment of social freedom, solidarity and social norms focused on personal and social well-being.

WHO defines mental health as well-being, in which an individual realizes his/ her own potential, can cope with the normal stresses of life, can work productively. In such a multidimensional conception, subjective well-being occupies a central position (Džuka, 2004; Diener, 2000; Argyle, 1987) with its two components - emotional (frequency of positive and negative emotions), and cognitive (life satisfaction). This construct, expressing the extent of satisfaction or dissatisfaction with fulfilment of individual needs or expectations and emphasizing the subjective aspect of experiencing, is the cause of individual differences in assessment of life well-being. Overall life satisfaction and self-control, along with other factors (vitality, satisfaction with personal life, social health) are considered by Koubelková (2001) a relatively separate factor of mental health, independent of a person's physical or social status. The above concepts are the corner stones of positive psychology, which in contrast to humanistic psychology (which it is based on) emphasizes human strengths and characteristics contributing to subjective well-being and mental health. This shows gradual transfer of psychologists' attention, from a negative paradigm to a person's positive inner mental resources 
to resist risks and dangers (salutogenetic view). In general, positive psychology is described as a science of positive individual features, life events and experiences, searching for possibilities enabling people to live a happier and more meaningful life (Mareš, 2001, Seligman, 2002).

After its initial orientation to the adult population, the attention of positive psychology has gradually transferred also to developmental processes, which are the source of the formation of optimism, creativity, self-efficacy, as its main attributes.

Application of positive psychology in schools and school facilities assumes formation of a so-called positive school model facilitating strengths of individuals (pupils, teachers, parents, other professionals such as school psychologists, etc.). On the other hand, positive psychology does not deny the existence of deficits, difficulties, disorders or problems at school and help to a pupil to return to "normality" (understood as the absence of disorders). On the contrary, according to Zelina (2014), it aims at directing the whole process of education to optimal functioning of school, to the search for sources for the development of personality as well as the whole society and subsequent reduction in traditional psychological and social interventions used. The programme of positive psychology includes both the effort for the prevention of negative phenomena and support of positive phenomena (Slezáčková, 2010). According to Seligman et al. (2003), it is necessary to refocus from repairing the worst things in life to maximizing what is the best in life. This means supporting optimal functioning of the human being, as well as the belief in and hope for the human being's success. Zelina (2014) believes that positive psychology introduces the principle of joy in learning, cognition and problem solving. This trend is based on three corner stones - use of positive emotions (of pupils, teachers and others, e.g., professionals in school, parents), positive personality characteristics (abilities, gift, talent) and positive social institutions (democracy, family).

Michael J. Furlong (2013) is the author of an internationally accepted and used model of mental health of children and young people at primary and secondary schools, and higher education institutions, built on 4 key positive mental health domains based on social psychology, self-image and cognitive therapy - belief in self, belief in others, emotional competence and engaged life. (In addition to the above four domains, the model of socio-emotional health includes also 12 indicators representing unique positive constructs of socio-emotional health and connected with four more general positive domains of socio-emotional health).

The first key domain is belief in self, consisting of 3 indicators based on constructs of socio-emotional learning (SEL) and relying on the theory of self-determination: self-efficacy, self-awareness and persistence. The second key domain is 
belief in others, containing 3 indicators derived from constructs of child resilience: school support, peer support and family support. The third domain is emotional competence containing 3 indicators also based on constructs of socio-emotional study: emotion regulation, empathy, self-control. Engaged life constitutes the last key domain. It consists of 3 indicators based on constructs of positive psychology: gratitude, zest and optimism (e.g., Furlong, Gilman, Huebner, 2014; Kirschman, Johnson, Bender, Roberts, 2009).

The above model is not a complex model of mental health. However, what is substantial is its practical use in the diagnostics of key psychological indicators serving as predictors and facilitators of a person's mental health, success at school, which emphasizes its use in the current educational practice.

\section{Research Problem}

There is a consensus in literature on the issue of protective factors and circumstances of mental health (Garmezy, 1991; Ungar, 2006). The most frequently mentioned ones include social skills and satisfactory interactions with peers, emotional stability, empathy, self-regulation, problem solving ability, positive self-concept and self-awareness as well as secure family, school and social bonds. That is why we decided to carry out research into the level of socio-emotional health in students at selected secondary schools in Slovakia. We also wanted to find out whether the assumption of a significant relationship between students' socio-emotional health and their happiness would be confirmed. In addition, we examined relationships between happiness and four basic dimensions of socio-emotional health (belief in self, belief in others, emotional competence and engaged life), and also their twelve psychological indicators (self-efficacy, self-awareness, persistence, family, peer, school support, emotion regulation, empathy, self-control, optimism, zest and gratitude).

Research question 1: What is the overall level of socio-emotional health in secondary school students?

Research question 2: What is the level of happiness in secondary school students?

Hypothesis 1: There is a significant positive relationship between socio-emotional health and subjective happiness in secondary school students.

Hypothesis 2: There is a significant positive relationship between happiness and four basic dimensions of socio-emotional health in secondary school students. 
Hypothesis 3: There is a significant positive relationship between happiness and psychological indicators of socio-emotional health in secondary school students.

\section{Research Sample}

The reason for research sampling were the basic ontogenetic characteristics of adolescence during which there is significant transformation of values, opinions and affects. It is a period of transition to autonomy, independence, moral responsibility, from consuming products of society and values to creating them. The mental activity changes not only in its expression and quality, but also in its efficiency, attitudes, social relationships, interests and aspirations - thus, the whole personality changes (Čačka, 2000). At the same time, there is new social inclusion of the individual, or change in his/her self-concept (Langmeier, Krejčírová, 1998). Sharing views about school is typical of this age category, as well as appreciation of teachers' efforts to enter into a relationship, communication and individual approach.

Due to the grammar schools/secondary vocational schools ratio 1:2 in Slovakia, 3 grammar schools and 6 secondary vocational schools were included in the research sample, but since we failed in obtaining consent of all head teachers, the research was carried out in 2 grammar schools and 4 vocational schools:

- Ján Papánek Grammar School (Bratislava)

- Private Grammar School (Košice)

- Secondary Vocational School of Electrical Engineering (Banská Bystrica)

- Secondary Vocational School of Civil Engineering (Nitra)

- Transport Academy (Žilina)

- Pedagogical and Social Academy (Prešov)

Table 1. Research Sample Characteristics

\begin{tabular}{|c|c|c|c|c|c|c|c|c|c|c|c|c|c|c|}
\hline & \multirow{2}{*}{\multicolumn{2}{|c|}{$\frac{\text { J. Papánek }}{\text { GS }}$}} & \multirow{2}{*}{\multicolumn{2}{|c|}{$\begin{array}{c}\text { Private } \\
\text { GS }\end{array}$}} & \multirow{2}{*}{\multicolumn{2}{|c|}{$\frac{\text { SVS }}{\text { Electric.E. }}$}} & \multirow{2}{*}{\multicolumn{2}{|c|}{$\frac{\text { SVS }}{\text { Civil E. }}$}} & \multirow{2}{*}{\multicolumn{2}{|c|}{$\begin{array}{l}\text { Transport } \\
\text { Academy }\end{array}$}} & \multirow{2}{*}{\multicolumn{2}{|c|}{$\frac{\text { Ped.\&Soc. }}{\text { Academy }}$}} & \multicolumn{2}{|c|}{ Total } \\
\hline & & & & & & & & & & & & & & \\
\hline & $\mathrm{N}$ & $\%$ & $\mathrm{~N}$ & $\%$ & $\mathbf{N}$ & $\%$ & $\mathrm{~N}$ & $\%$ & $\mathrm{~N}$ & $\%$ & $\mathbf{N}$ & $\%$ & $\mathbf{N}$ & $\%$ \\
\hline Girls & 31 & 75.61 & 25 & 69.44 & 20 & 40 & 12 & 25.53 & 38 & 59.38 & 40 & 88.89 & 166 & 58.66 \\
\hline Boys & 10 & 24.39 & 11 & 30.56 & 30 & 60 & 35 & 74.47 & 26 & 40.62 & 5 & 11.11 & 117 & 41.34 \\
\hline Total & 41 & 100 & 36 & 100 & 50 & 100 & 47 & 100 & 64 & 100 & 45 & 100 & 283 & 100 \\
\hline
\end{tabular}


Picture 1. Research Sample Composition by School Type

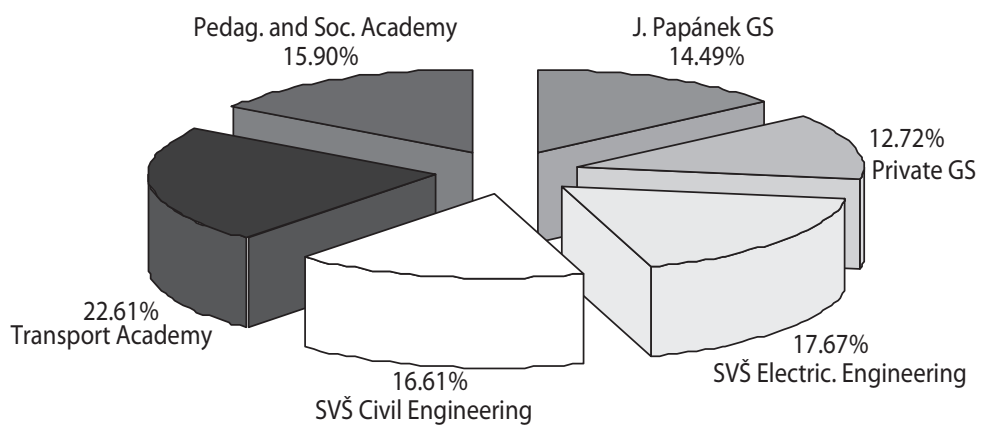

The research sample consisted of students of the third form, since it was assumed that precisely third form students having spent two years at secondary school were relatively well adjusted to the environment, had built stronger social relationships based mainly on the belief in school mates, teachers. Thus, they could seriously present their views on their experience, emotional competence and engaged life.

\section{Instrument and Procedures}

SEHS - Social-Emotional Health Survey (Furlong at al., 2013) - version for secondary school students (SEHS-S).

SEHS is based on the assumption that success in study partially depends on the student's life conditions strengthening the development of internal psychological dispositions connected with positive belief in oneself, belief in others, emotional competence and engaged living. SEHS finds out the current level of mental health and individual levels of its indicators. It is a questionnaire method aimed at finding out the general level of respondents' socio-emotional health, as well as its psychological indicators and dimensions. The questionnaire allows for measuring students' mental health and identifying those who need preventive or intervention services for their personal growth. The total score of mental health is expressed by a covitality index. The questionnaire consists of 37 items with answers given either on 4-point scales ( 1 - not at all true of me, 4 - very much true of me) or on 5 -point scales ( 1 - not at all, 5 - extremely) in items $31-37$. The score in individual domains acquires values from 9 to 36 . The covitality index acquires values from 36 to 150 (low covitality index $\leq 85$ points and fewer, lower mean index - 86-106 
points, higher mean index - 107-127 points and high covitality index $\geq 128$ and more points).

Cronbach's alpha of socio-emotional health domains and their 12 indicators ranges from 0.614 to 0.858 .

The Subjective Happiness Scale (SHS) (Ljubomirsky, Lepper, 1999) measures global happiness. It consists of 4 items aimed at finding out the global level of happiness. In the first item, respondents characterize their own happiness, in the second item they rate their happiness relative to peers, and the other two items are oriented to happiness rating relative to individuals around respondents. The intensity of consent is expressed by means of a 7-point Likert scale.

The author gives the psychometric characteristic of the tool internal consistency by means of Cronbach's alpha for individual items in the range from 0.79 to 0.94 . Reliability measured by the test-retest method was tested over 3 weeks and 1 year, with results ranging from 0.55 to 0.90 (Ljubomirsky, Lepper, 1999).

The above-mentioned methods enabled us to gather data that were subjected to mathematical and statistical analysis using the SPSS program.

\section{Data Analysis}

Since our primary concern was to find out mutual relationships, correlation analysis was used in addition to descriptive statistics and normality testing. Distributions of individual socio-emotional health dimensions were symmetric. However, this was not true for their individual indicators, thus Spearman's rank correlation coefficient was used.

\section{Research Results}

Table 2. Description of SEH-S and SHS variables $(\mathrm{N}=283)$

\begin{tabular}{lccccccc}
\hline & AM & ME & Min & Max & SD & Sk & Ku \\
\hline BELIEF IN ONESELF & 26.13 & 26 & 14 & 34 & 4.07 & -0.268 & -0.442 \\
\hline Self-Efficacy & 9.72 & 9 & 5 & 12 & 1.498 & -0.486 & -0.25 \\
\hline Self-Awareness & 9.36 & 9 & 3 & 12 & 1.956 & -0.648 & -0.185 \\
\hline Persistence & 7.06 & 6 & 3 & 12 & 2.143 & 0.155 & -0.702 \\
\hline BELIEF IN OTHERS & 28.36 & 29 & 12 & 36 & 4.704 & -0.71 & 0.586 \\
\hline
\end{tabular}




\begin{tabular}{lccccccc}
\hline & AM & ME & Min & Max & SD & Sk & Ku \\
\hline School Support & 8.29 & 8 & 3 & 12 & 2.505 & -0.091 & -1.094 \\
\hline Family Coherence & 10.03 & 10 & 3 & 12 & 2.14 & -1.156 & 0.954 \\
\hline Peer Support & 10.05 & 11 & 3 & 12 & 2.303 & -1.39 & 1.523 \\
\hline EMOTIONAL COMPETENCE & 27.58 & 27 & 19 & 36 & 3.342 & 0.077 & -0.42 \\
\hline Emotion Regulation & 8.45 & 8 & 3 & 12 & 1.336 & -0.596 & 0.536 \\
\hline Empathy & 8.36 & 8 & 3 & 12 & 1.788 & -0.147 & 0.155 \\
\hline Self-Control & 9.02 & 9 & 3 & 12 & 2.056 & 0.122 & -0.078 \\
\hline ENGAGED LIFE & 27.39 & 27 & 11 & 36 & 4.587 & -0.442 & 0.479 \\
\hline Optimism & 8.93 & 9 & 3 & 12 & 2.001 & -0.445 & -0.178 \\
\hline Zest & 8.22 & 8 & 3 & 12 & 2.294 & -0.192 & -0.667 \\
\hline Gratitude & 10.24 & 10 & 4 & 12 & 1.577 & -0.735 & 0.524 \\
\hline COVITALITY INDEX & 109.45 & 88 & 38 & 149 & 6.589 & -0.398 & 1.559 \\
\hline HAPPINESS & 4.94 & 5 & 1 & 7 & 1.175 & -0.71 & 0.586 \\
\hline
\end{tabular}

Legend: AM - Mean, ME - Median, Min - Minimum, Max - Maximum SD - Standard Deviation, Sk - Skewness, Ku - Kurtosis

For better illustration of the variables distribution, boxplots of the individual socio-emotional health dimensions, Covitality Index and Happiness are presented below.

The mean of the Belief in Oneself dimension was 26.13 at the $95 \%$ confidence interval in the range from 25.47 to 26.69 .

Graph 1. Boxplot of the Belief in Oneself dimension

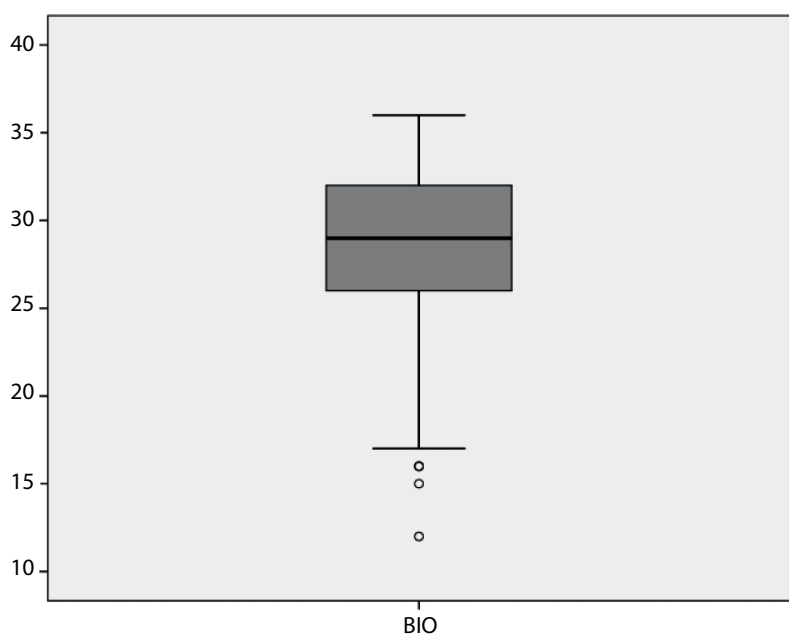


The mean of the Belief in Others dimension was 28.36 at the $95 \%$ confidence interval in the range from 27.66 to 29.05 .

Graph 2. Boxplot of the Belief in Others dimension

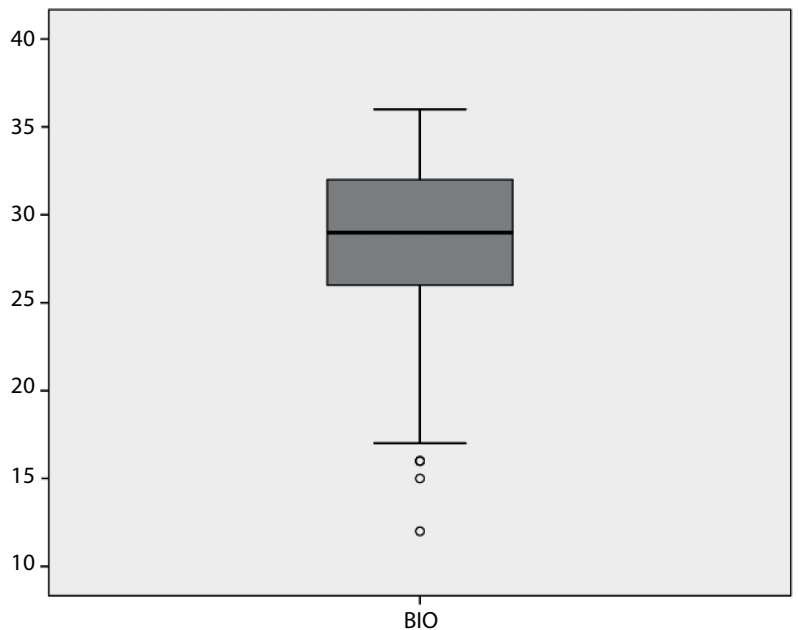

The mean of the Emotional Competence dimension was 27.58 at the $95 \%$ confidence interval in the range from 27.07 to 28.09 .

Graph 3. Boxplot of the Emotional Competence dimension

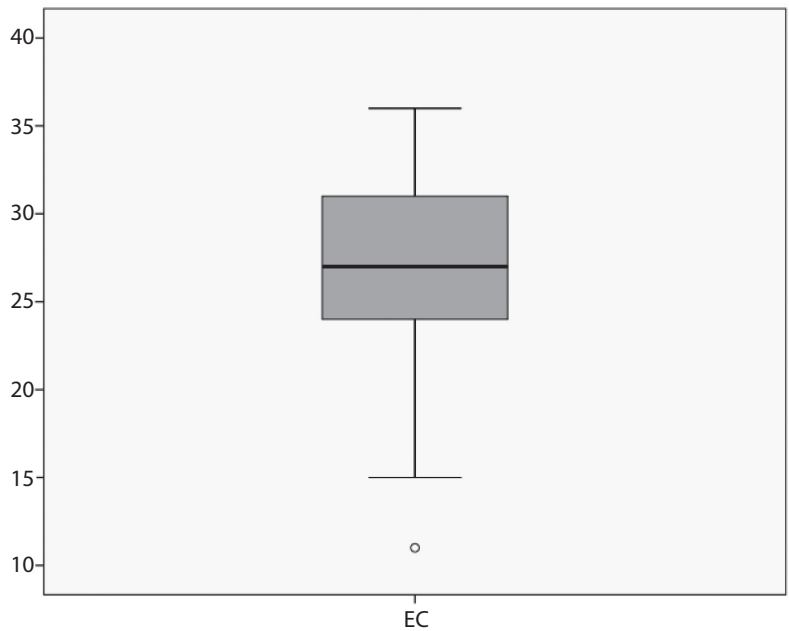


The mean of the Engaged Life dimension was 27.39 at the $95 \%$ confidence interval in the range from 26.71 to 28.07 .

Graph 4. Boxplot of the Engaged Life dimension

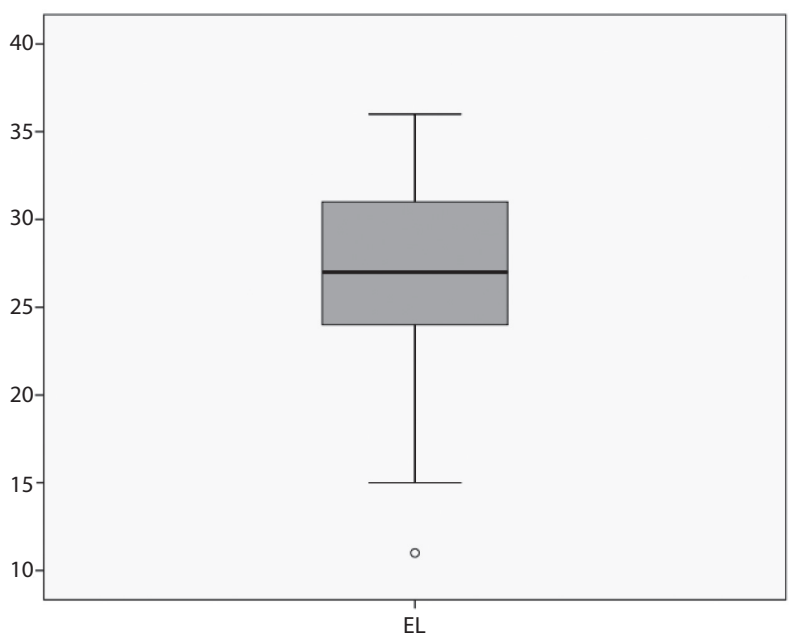

The mean Covitality Index of our respondents was 109.46 in the confidence interval from 107.72 to 111.30 . Thus, it can be stated that they reported a mean Covitality Index, situated in the higher mean range.

Graph 5. Boxplot of the Covitality Index

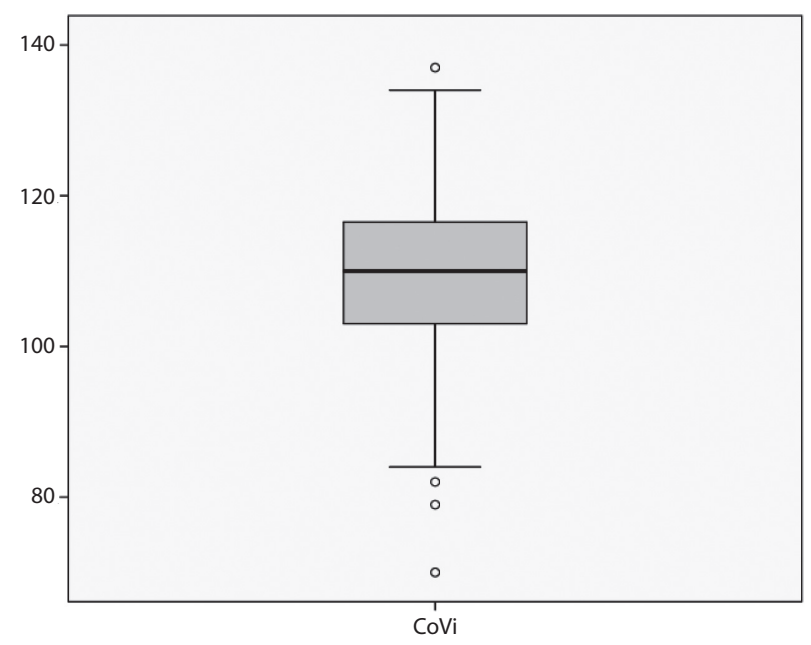


Subjective Happiness indicated normal distribution. The mean was 4.94 at the $95 \%$ confidence interval in the range from 4.75 to 5.12 .

Graph 6. Boxplot of Subjective Happiness

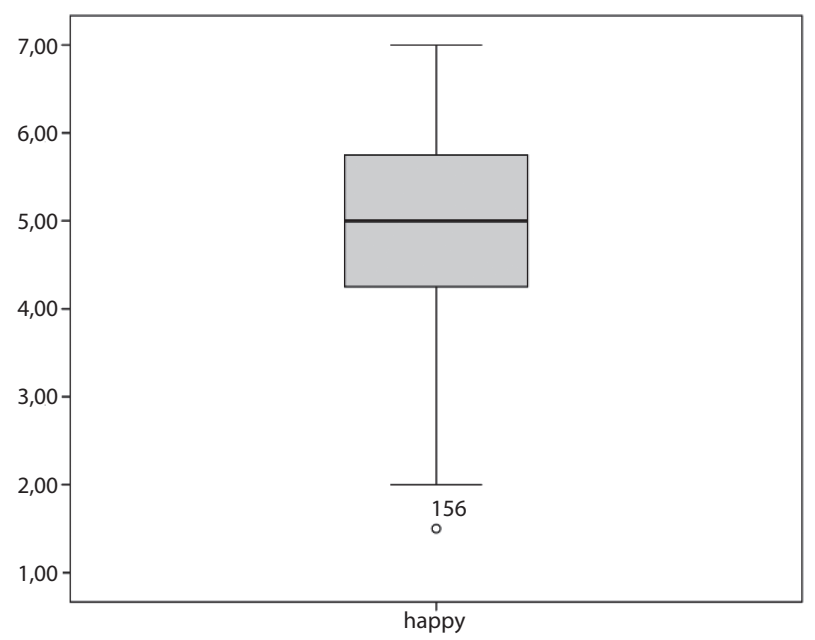

All the confidence intervals were relatively narrow, indicating a relative accuracy of the mean values of individual variables.

Table 3 presents tests for statistical significance of correlation coefficients between the dimensions and indicators of socio-emotional health and Subjective Happiness.

Table 3. Correlation coefficients between Subjective Happiness and variables of socio-emotional health $(\mathrm{N}=283)$

\begin{tabular}{lcc}
\hline & Spearman's rho & Sig. \\
\hline BELIEF IN ONESELF & 0.522 & 0.000 \\
\hline Self-Efficacy & 0.435 & 0.000 \\
\hline Self-Awareness & 0.396 & 0.003 \\
\hline Persistence & 0.351 & 0.001 \\
\hline BELIEF IN OTHERS & 0.255 & 0.000 \\
\hline School Support & 0.214 & 0.060 \\
\hline Family Coherence & 0.266 & 0.000 \\
\hline Peer Support & 0.298 & 0.000 \\
\hline EMOTIONAL COMPETENCE & $\mathbf{0 . 1 2 5}$ & $\mathbf{0 . 0 4 6}$ \\
\hline
\end{tabular}




\begin{tabular}{lcc}
\hline & Spearman's rho & Sig. \\
\hline Emotion Regulation & 0.096 & 0.054 \\
\hline Empathy & 0.095 & 0.078 \\
\hline Self-Control & 0.018 & 0.491 \\
\hline ENGAGED LIFE & 0.425 & 0.003 \\
\hline Optimism & 0.501 & 0.000 \\
\hline Zest & 0.432 & 0.000 \\
\hline Gratitude & 0.423 & 0.000 \\
\hline COVITALITY INDEX & 0.546 & 0.000 \\
\hline
\end{tabular}

Table 3 shows confirmation of our assumption of a significant relationship between socio-emotional health (covitality index) and Subjective Happiness $(\mathrm{r}=$ $0.546 ; p=0.000$ ). It is a positive moderate relationship. In addition, positive correlations at the $0.1 \%$ statistical significance level were found between Happiness and Belief in Oneself $(r=0.522)$, Optimism $(r=0.501)$, Self-Efficacy $(r=0.435)$, Zest $(r=0.432)$, Gratitude $(r=0.423)$, Peer Support $(r=0.298)$, Family Coherence $(r=0.266)$, and Belief in Others $(r=0.255)$. At the $1 \%$ statistical significance level, Happiness correlated with Engaged Life $(r=0.425)$, Self-Awareness $(r=$ $0.396)$, and Persistence $(r=0.351)$. At the $5 \%$ statistical significance level, a positive correlation was indicated between Happiness and the Emotional Competence dimension $(r=0.125)$, which, however, was not confirmed for its indicators.

\section{Discussion}

The author of the basic model himself states that, e.g., in the USA, only about $2 \%$ of schools screen their pupils for mental health (Romer, McIntosh, 2005), which is indeed little. However, the situation is not better in European countries. Our research analysis of socio-emotional health and subjective happiness in students at selected secondary schools revealed that the summary score of our respondents' socio-emotional health reached the mean index of covitality, situated in the higher mean range, and their mean value of happiness was $\mathrm{AM}=4.94$.

Hypothesis 1 assumed a significant positive relationship between socio-emotional health and subjective happiness in secondary school students. Correlation analysis confirmed that there is a connection between socio-emotional health and happiness, and that mentally healthy students experience more intense feelings of happiness. Our research did not deal with the causality of such relationships. On the basis of the above we can state that our Hypothesis 1 was confirmed. 
Hypothesis 2 assumed a significant positive relationship between happiness and four basic dimensions of socio-emotional health in secondary school students, and Hypothesis 3 assumed a significant positive relationship between happiness and psychological indicators of socio-emotional health in secondary school students. Our findings confirmed that there is a moderate positive relationship between Happiness and Belief in Oneself, one of the socio-emotional health domains; similar as between Happiness and indicators of Belief in Oneself. There is a moderate positive correlation between Happiness and another socio-emotional health domain - Engaged Life. There is also the same moderate positive correlation between Happiness and indicators of Engaged Life - Optimism, Zest and Gratitude. However, the correlation coefficients between the Belief in Others dimension, its indicators and Happiness confirm that the correlation between these variables is weak, very close to moderate values. A weak correlation between Happiness and the Emotional Competence dimension closes our findings enabling us to state that Hypothesis 2 was confirmed. Surprisingly, no relationship whatsoever was found between Happiness and indicators of Emotional Competence. This could indicate that more empathic young people are not happier than less empathic ones and that happiness does not affect either regulation of their emotions or their self-regulation, which makes us state that Hypothesis 3 was not confirmed.

This result may notify us of many reserves in the approach of secondary schools or their staff to their students.

\section{Conclusions}

We are aware of several limitations of our research. For instance, using non-standardized methods, SEHS-S and SHS, despite their reliability proved to be stable and high. Another limitation is the research sample size, which, due to the reality of the Slovak school system as well as school head teachers' distrust of research in their schools, was the reason why our research was carried out in 2 grammar schools and 4 secondary vocational schools. Nevertheless, we decided to reveal what mental health of our secondary school students is like and what its relationship to happiness is. The merits of our research can be seen also in the contribution to the validation of the SEHS-S tool as a mental health screening method since it enables us to determine the level of socio-emotional health in pupils and students at various school types and stages and thus significantly contributes to the improvement of the quality of educational practice. Also, we would like to co-operate with other subjects on its standardization. 
As already suggested in the theoretical background, the goal of positive psychology in the school setting is to change the direction from "repairing" what is bad to supporting and cultivating what is good. In recent decades school has been required to focus not only on performance, the amount of knowledge or academic competence. It should create adequate conditions for the development of the highest possible amount of personality competences contributing to an increase in the level of mental health by creating a safe environment, good interpersonal relationships, favourable social climate, support of self-confidence, positive self-concept and, last but not least, better understanding of oneself. One way to begin is a regular self-evaluation of students' and teachers' mental health, which may also work as prevention of various emotional, social, or behavioural problems. Various long-term preventive programmes (Way to Emotional Maturity, Say it Directly, Do not Destroy your Wise Body, Tolerance Development Programme, etc.) may fulfil a protective function for mental health. Stehlíková (2016) emphasizes the necessity of change in professional training of future teachers. To be able to respond effectively and adequately in school social interactions mainly with pupils and parents by applying principles of positive psychology, teachers need to develop modifications of various important competences systematically and continuously also by means of various intervention programmes.

And last but not least, it is necessary to support school's good and effective co-operation with family, school psychologists, special pedagogues, social and health-care staff, and working together solve any problems in behaviour and learning that occur at school and that disrupt optimal social and educational conditions.

\section{References}

Argyle, M. (1987). Psychology of happiness. New York: Methuen, 1987.

Becker, A.E. (1995). Body, Self, and Society: the View from Fiji. Philadelphia: University of Pennsylvania Press.

Čačka, O. (2000). Psychologie. Brno: Doplněk, 377.

Diener, E. (2000). Subjective well - being: the science of happiness, and a proposal for a national index. In American Psychologist, 55, 34-43.

Džuka, J. (2004). Kvalita života a subjektívna pohoda - teórie, modely, podobnost' a rozdiely. [cit. 2006-03-12]. Available on the Internet: <http://www.pulib.sk/elpub/FF/Dzuka3/ index.htm>.

Ďuricová, L. (2016a). Adolescent School-Related Self Concept in Relation to Adolescent Personality. In The New Educational Review, 43, (1), 263-273

Ďuricová, L., Hašková, M. (2016b). Spôsob výchovy v rodine ako zdroj sebapoňatia pubescenta. In Pedagogika.sk [online], 7, (1), 7-21. Available on: http://www. 
casopispedagogika.sk/studie/duricova-v-haskova-monika-sposob-vychovy-v-rodine-ako-zdroj-sebaponatia-pubescenta.html

Furlong, M.J. \& You, S. \& Renshaw, T.L. \& O Malley, M.D. \& Rebelez, J. (2013). Preliminary development and validation of the Social and Emotional Health Survey for secondary students. In Child Indicators Research, 6. Springer. 753-775.

Furlong, M.J., Gilman, R. \& Huebner, E.S. (Eds.). (2014). Covitality: A Synergistic Conception of Adolescents' Mental Health. Handbook of Positive psychology in the Schools (second edition). New York, NY: Routledge/Taylor\&Francis, p. 24.

Garmezy, N. (1991). Resiliency and vulnerability to adverse developmental outcomes associated with poverty. In American Behavioral Scientist, 34, 416-430.

Kirschman, K.J.B., Johnson, R.J., Bender, J.A., \& Roberts, M.C. (2009). Positive psychology for children and adolescents: Development, prevention, and promotion. In S.J. Lopez \& C.R. Snyder (Eds.), The Oxford handbook of positive psychology ( $2^{\text {nd }}$ ed., pp. 133-148). New York, NY: Oxford

Koubeková, E. (2001). Vztahy medzi percipovanou sociálnou oporou a niektorými osobnostnými charakteristikami adolescentov. In Psychológia a patopsychológia dietata. 36, (1), 39-49.

Kozoň, A. (2013). Sociálna práca a jej cesty k človeku: Kam kráča...? Trenčín: SpoSoIntE.

Langmeier, J. \& Krejčíŕová, D. (1998). Vývojová psychologie. Vydání 3. přepracované a doplněné vydání 1 . Praha: Grada Publishing.

Lyubomirsky, S. \& Lepper, H. (1999). A measure of subjective happiness: Preliminary reliability and construct validation. In Social Indicators Research, 46, 137-155. The original publication is available at www.springerlink.com.

Mareš, J. (2001). Pozitivní psychologie: důvod k zamyšlení i výzva. In: Československá psychologie, 45, (2), 97-117.

Romer, D., \& McIntosh, M. (2005). The Roles and Perspectives of School Mental Health Professionals in Promoting Adolescent Mental Health. In Treating and Preventing Adolescent Mental Health Disorders. Oxford University press.

Rycroft, CH. (1993). Kritický slovník psychoanalýzy. Praha: Psychoanalytické nakladatelství, 1993.

Seligman, M.E.P. (2002). Authentic Happiness: Using the New Positive Psychology to Realize Your Potential for Lasting Fulfilment. [Electronic version]. New York: Free Press.

Seligman, M.E.P. \& Peterson, CH. (2003). Positive clinical psychology. In L.G. Aspinwall \& U.M. Staudinger. (Eds.), A Psychology of human strengths: Fundamental questions and future directions for a positive psychology. Washington, DC: APA. 305-316.

Slezáčková, A. (2010). 21. století přináší pozitivní psychologii. In Psychologie dnes, 16, (6), $32-33$.

Stehlíková, J. (2016). Rozvíjanie empatie v pomáhajúcich profesiách. Banská Bystrica: Belianum. Vydavatelstvo Univerzity Mateja Bela. 198s.

Ungar, M. (2006). Nurturing hidden resilience in at-risk youth across cultures. In Journal of the Canadian Academy of Child and Adolescent Psychiatry, 15, (2), 53-58.

Zelina, M. (2014). Pozitívna psychológia v škole. In: Učitelské noviny, 57, 4-5. 